\title{
URGENSI MANAJEMEN PENDIDIKAN DALAM PENGEMBANGAN LEMBAGA PENDIDIKAN ISLAM
}

\author{
Abu Choir \\ abuchoir.smg@gmail.com \\ FITK IAIN Surakarta \\ Jawa Tengah, Indonesia
}

\begin{abstract}
:
Management of education is recognized as one of the most important aspects of education today. It thus because management education has been supporting the activities of education quality, and even has a feature and an indication of the quality of education itself. Even the management of education and not the main element of education, but education quality is often measured by this educational management activities. Therefore, the management of a good education should be pursued as ikhtiyar develop the quality of education.

The existence of the concept of adult education and management practices was felt necessary to have a new twist. Attractions such as management education is an applied science of management in education. As the science develops from the business world, the norms and ethics of scientific management can not be separated from economic motives, human relations, and organizational aspects. Yet there are things perceived fundamental education can not simply approach the business. Even as prevalent in western scientific, moral and ethical issues are often separated from the development of management science itself.

This paper emphasizes on efforts to find an alternative to the new face of management education, with a touch of Islamic values and ethics to develop Islamic educational institutions.

Keywords:Concepts, Islamic Education Management
\end{abstract}

Abstrak:

Manajemen pendidikan diakui sebagai salah satu aspek terpenting dalam pendidikan dewasa ini.Hal demikian karena manajemen pendidikan telah menjadi aktivitas penopang mutu pendidikan, bahkan telah menjadi ciri dan indikasi dari mutu pendidikan itu sendiri.Sekalipun manajemen pendidikan, bukan unsur utama pendidikan, tetapi pendidikan bermutu seringkali diukur dari aktivitas manajemen pendidikan ini.Oleh karena itu, manajemen pendidikan yang baik perlu diupayakan sebagai ikhtiyar mengembangkan mutu pendidikan.

Keberadaan konsep dan praktik manajemen pendidikan dewasa ini dirasakan perlu ada sentuhan baru.Hal demikian karena manajemen pendidikan merupakan ilmu terapan manajemen dalam dunia pendidikan. Sebagai ilmu yang berkembang dari dunia bisnis, norma dan etika keilmuan manajemen tidak dapat dipisahkan dari motif-motif ekonomi, hubungan manusiawi, dan aspek-aspek organisasi. Padahal dirasakan ada hal-hal fundamental pendidikan yang tidak bisa sekedar dengan pendekatan bisnis.Bahkan sebagaimana lazim pada keilmuan barat, persoalan moral dan etika seringkali terlepas dari pengembangan ilmu manajemen itu sendiri.

Tulisan ini lebih menekankan pada upaya menemukan alternatif bagi wajah baru manajemen pendidikan dengan memberi sentuhan nilai dan etika islami untuk mengembangkan lembaga pendidikan Islam.

Kata Kunci:Konsep, Manajemen Pendidikan Islam 


\section{Pendahuluan}

Menyitir pernyataan Max Ways wartawan senior majalah bisnis Fortune, jika abad 19 merupakan abad industri, maka abad 20 adalah abad manajemen (Hadi Satyagraha, 2013: 7). Barangkali dalam sejarah ilmu pengetahuan, tidak akan ditemukan ilmu pengetahuan yang berkembang pesat dan begitu mudah diterima seperti manajemen. Sebagai disiplin ilmu sejak pertama kali digulirkan pada akhir abad 19, manajemen telah mengokohkan peran dan fungsinya dalam memenuhi kebutuhan manusia dan organisasi. Melalui manajemen berbagai organisasi kemasyarakatan-organisasi ekonomi, organisasi sosial, dan organisasi politik-dapat memaksimalkan perannya untuk memenuhi kebutuhan manusia dalam bidang ekonomi, sosial, dan politik. (Hadi Satyagraha, 2013 : 10).

Gambar 1. Manusia, Organisasi, dan Manajemen

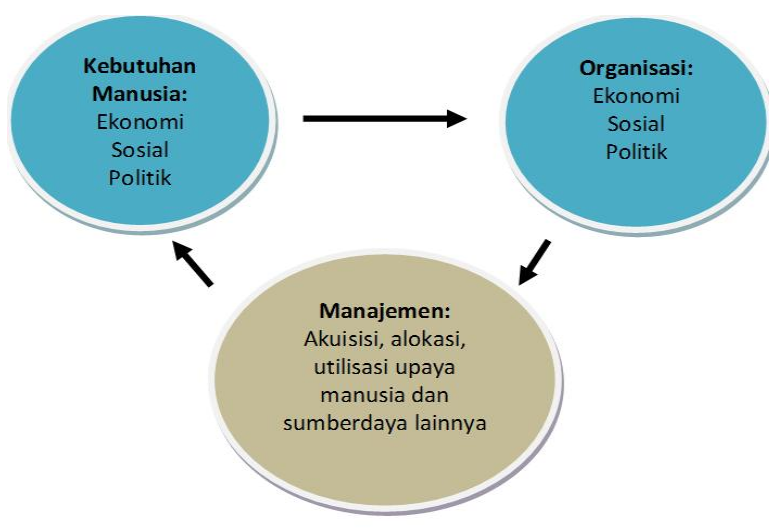

Profesi manajer merupakan salah satu profesi yang paling didambakan orang di dunia saat ini. Di Amerika Serikat, bila ingin kaya, disarankan menjadi chief executive officer (CEO) sebuah perusahaan. Di Indonesia, gaji CEO BUMN sangat tinggi, sehingga sempat membuat iri Presiden Susilo Bambang Yudhoyono (SBY) sebagai CEO Republik Indonesia (Hadi Satyagraha, 2013: 8). Media Massa juga turut memopulerkan profesi manajer ketimbang profesi lainnya, bahkan dengan semakin populernya aktivitas bisnis dan entrepreneurship akhir-akhir ini profesi manajer semakin banyak diimpikan anakanak muda.

\section{Urgensi Manajemen bagi Pendidikan}

Peran manajemen bagi peningkatan mutu pendidikan dewasa ini semakin diakui, bahkan dianggap sebagai jantungnya pendidikan. Munif Chatib pelopor dan penggerak "Sekolahnya Manusia" menyatakan, bahwa dalam suatu intitusi sekolah, apapun jenjangnya terdapat hal yang paling penting, yaitu manajemen sekolah yang menjadi jantungnya (Munif Chatib, 2013: 35). Sebagaimana dalam kehidupan manusia, jantung merupakan pusat kehidupan. Dengan demikian, manajemen sekolah menjadi unsur yang terpenting dalam kegiatan sekolah.

Demikian juga hal yang terjadi pada lembaga pendidikan Islam (LPI). Beberapa kasus kebangkitan lembaga-lembaga pendidikan Islam (pesantren, madrasah, sekolah Islam) di beberapa daerah secara faktual juga ditopang oleh pengembangan manajemennya.Manajemen dipercaya mampu menjadi salah satu alternatif solusi problematika lembaga pendidikan Islam tersebut.

\section{Arif Furchan (2004: 67-68)} menyatakan bahwa kenyataan adanya lembaga-lembaga madrasah yang berhasil maju dan berkembang, bahkan mampu melampaui sekolah-sekolah non madrasah dalam favorisitas, pilihan orang tua, bahkan kesediaan orangtua membayar mahal bukan sekedar kebetulan. Madrasah-madrasah tersebut ternyata melakukan berbagai gerakan menuju kemajuan. Ada yang mengembangkan sistem pendanaan, pengembangan SDM, 
pengembangan kepemimpinan, dan ada yang mengembangkan time work. Gerakan tersebut mengarah pada pola-pola kerja manajemen pendidikan yang baik. Keberhasilan tersebut perlu mendapat perhatian dan dijadikan pemacu gerak bagi kemajuan LPI yang lain.

Di Indonesia, untuk mewujudkan pendidikan bermutu, sejak era tahun 1990 pemerintah mulai memberikan perhatian pada upaya pergeseran orientasi pembaharuan pendidikan dengan lebih menfokuskan pada penataan manajemen pendidikan ini, terutama penguatan manajemen sekolah (Arismunandar,makalah 2004). Bahkan di negara yang lebih maju, jauh sebelum itu perhatian pada perlunya manajemen pendidikan dalam mendorong peningkatan mutu pendidikan sudah dilakukan. Munculnya gerakan "sekolah baik" pada tahun 1970-an (N Postman \& C Weingartner,1973), "sekolah unggul" pada tahun 1980-an (W.W Wayson, \& B.M Mitchell,1988), dan "sekolah efektif" pada tahun 1990-an , (H.Silver, 1994) menunjukkan besarnya perhatian terhadap proses dan sistem manajemen persekolahan.

Rosnani Hashim menyebutkan bahwa salah satu pilar untuk mendukung pembangunan bangsa ialah dengan mensukseskan dan mengefektifkan sistem pendidikan. Dan dari banyak studi menyebutkan bahwa pendidikan yang efektif dan sukses didukung penerapan manajemen yang baik. Hal demikian seperti studi terhadap 300 sekolah yang dilakukan oleh Berman dan Mc Laughlin, bahwa kesuksesan sekolah yang menjadi sampel studinya lebih dominan karena didukung oleh kepala sekolah sebagai manajer pendidikan (Rosnani Hashim, 2012: 162).
Berdasarkan uraian tersebut di atas, keberadaan manajemen dalam rangka meningkatkan mutu pendidikan merupakan hal yang urgen dan mendesak. Melalui manajemen ini, setiap proses pendidikan akan dapat dipertanggungjawab-kan dan diikuti setiap detail proses kegiatannya. Manajemen pendidikan juga telah dijadikan indikasi bagi mutu pendidikan dalam setiap jenjang pendidikan.

\section{Kedudukan Manajemen dalam Pendidikan}

Manajemen pendidikanmerupakan terapan dari ilmu manajemen pada dunia pendidikan (Nawawi Hadari,1997). Hal demikian merupakan bagian perkembangan ilmu dan teknologi manajemen sesuai dengan orientasi para ilmuwan pada pengaturan dan keteraturan pengelolaan pendidikan, sehingga lahir manajemen pendidikan (Makmur,2008: 100). Disamping itu, manajemen pendidikan juga merupakan bentuk bukti bahwa ilmu dan teknologi manajemen berkembang dalam pemikiran (mind) manusia yang diperkuat dengan kemampuan berpikir (the knower) dari seluruh fenomena yang diperoleh dari pengalaman individu dan kemampuan menalar (the knowing) dalam memberikan argumentasi atau penjelasan terhadap fenomena yang diperoleh dari pengalaman oleh manusia yang bersangkutanManajemen pendidikan merupakan ilmu yang membahas pendidikan dari sudut pandang kerjasama dalam proses mencapai tujuan pendidikan (Tim Dosen Administrasi Pendidikan UPI, 2011: 10). Proses kerjasama tersebut melibatkan secara penuh konstribusi berbagai aspek yang dipandang perlu dan positif dalam usaha mencapai keberhasilan tersebut, melalui 
harmonisasisedemikian rupa benda atau material-seperti uang dan fasilitas, spiritual-seperti keyakinan dan nilainilai, ilmu pengetahuan-seperti ilmu dan teknologi, maupun manusia atau human. Penggunaan berbagai sumberdaya tersebut dilakukan secara efektif dan efisien untuk mencapai tujuan yang telah ditentukan. Manajemen pendidikan didefinisikan sebagai ilmu pengetahuan yang membahas pendidikan dari sudut pandang proses kerjasama antar manusia dalam mengembangkan potensi peserta didik melalui perubahan sikap dalam pembelajaran untuk mencapai tujuan pendidikan, secara efektif dan efisien.

\section{Gambar 2: Sumbu Kegiatan lembaga} pendidikan Islam

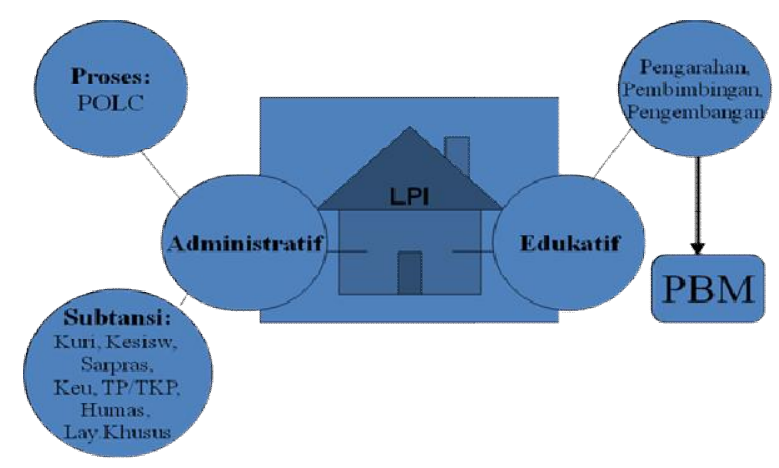

Aplikasi manajemen pada pendidikan merupakan proses atau aktivitas mengembangkan kegiatan kerjasama sekelompok orang dalam memberdayakan berbagai sumber pendidikan agar berdayaguna secara efektif dan efesien untuk mencapai tujuan pendidikan. Manajemen memberikan sentuhan melalui perencanaan, pengorganisasian, kepemimpinan, dan pengendalian pada input pendidikan agar dapat digunakan dan mendukung proses pendidikan, sehingga output pendidikan dapat terwujud secara efektif dan efesien, dan menjadi outcome yang berkualitas bagi pendidikan. Manajemen berkerja secara integral bersama proses PBM untuk mencapai tujuan pendidikan. Aktivitas manajemen sebagai kerja administratif, sedangkan PBM sebagai kerja edukatif.

\section{Gambar 3: Alur Kerja Manajemen dalam Aktivitas Pendidikan}

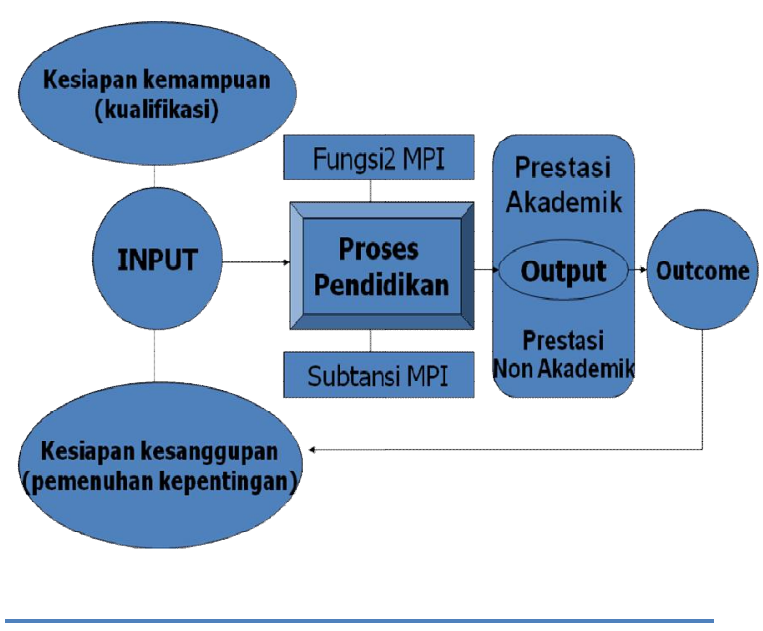

Ad.l. Input pendidikan

Input pendidikanialah segala sesuatu. yang harus tersedia karena dibutuhkan untuk berlangsungnya proses pendidikan. Input terdiri atas sumberdaya, perangkat lunak, dan harapan-harapan sebagai pemandu bagi berlangsungnya proses. Input sumberdaya meliputi (1)sumber daya manusia (SDM) yaitu: (a) kepala sekolah/madrasah; (b)guru, (c)PSB, (d)siswa; (e)karyawan; (f)keamanan; dan (2)sumberdaya selebihnya, yaitu: (a)peralatan; (b)perlengkapan; (c)uang, (d)buku dan lain sebagainya (Dikdasmen, 2001). Input perangkat lunak meliputi struktur organisasi sekolah, peraturan perundangundangan, deskripsi tugas, rencana, program, dan lain sebagainya. Input harapan-harapan berupa visi, misi, tujuan dan sasaran-sasaran yang ingin dicapai oleh sekolah.

Kesiapan input, baik kesanggupan maupun kemampuan sangat diperlukan agar proses dapat berlangsung dengan baik. Manajemen menganalisis berbagai kesiapan input tersebut berdasarkan 
proses pendidikan yang akan dilakukan. Setiap input yang dibutuhkan proses akan diberdayakan dan diharmonisasikan sedemikian rupa dalam kerja proses pendidikan melalui perencanaan, pengorganisasian, kepemimpinan, dan pengendalian. Input yang telah siap diproses melalui proses pendidikan agar mencapai tujuan yang telah ditetapkan.

\section{Ad.2 Proses pendidikan}

Proses pendidikan merupakan kegiatan berubahnya "sesuatu" menjadi "sesuatu yang lain. Sesuatu yang berpengaruh terhadap berlangsungnya proses disebut input, sedangkan sesuatu dari hasil proses disebut output. Dalam.pendidikan berskala mikro (tingkat sekolah), proses yang dimaksud adalah proses pengambilan keputusan, proses pengelolaan kelembagaan, proses pengelolaan program, proses belajar mengajar, dan proses monitoring dan evaluasi. Proses dikatakan bermutu tinggi apabila pengoordinasian dan penyerasian serta pemaduan input sekolah (guru, siswa, uang, kurikulum, peralatan, dll.) dilakukan secara harmonis, sehingga mampu menciptakan situasi pembelajaran yang menyenangkan (enjoyable learning), mampu mendorong motivasi dan minat belajar, dan benar-benar mampu memberdayakan peserta didik. Memberdayakan dalam hal ini mengandung arti bahwa peserta didik tidak sekedar menguasai pengetahuan yang diajarkan oleh guru, akan tetapi pengetahuan tersebut juga menjadi muatan nurani peserta didik, dilakukan kemudian dalam kehidupan sehari-hari dan yang lebih penting lagi peserta didik mampu belajar cara belajar (mampu mengembangkan diri).
Proses yang baik ialah proses yang disengaja melalui tahapan-tahapan manajemen yang baik. Manajemen yang baik akan menjadikan proses pendidikan berkualitas. Beberapa indikasi proses pendidikan lembaga pendidikan bermutu dalam prespektif manajemen, yaitu sebagi berikut:

1. Keefektifan Proses Pembelajaran
a. Menggunakan perencanaan pembelajaran dalam bentuk Prota, Primes, dan Silabi
b. Menggunakan metode yang dapat mengaktifkan dan memandirikan siswa dalam pembelajaran
c. Memanfaatkan sumberdaya lingkungan sebagai media dalam pembelajaran
d. Melakukan evaluasi dan penilaian dengan instrumen yang standar
e. Melakukan umpan balik dari hasil evaluasi dan penilaian untuk perbaikan proses pembelajaran

2. Kepemimpinan Sekolah/Madrasah yang kuat

a. Memiliki visi dan misi yang jelas
b. Memiliki kemampuan entrepreneur

c. Memiliki integritas dan keperacayaan diri yang tinggi
d. Mempunyai kemampuan manajerial

e. Memiliki gagasan pembaharuan

f. Mampu memotivasi terwujudnya tim kerja yang solid

3. Memiliki Budaya Mutu
a. Penggunaan sistem informasi yang jelas
b. Pembagian kewenangan
c. Pemberian ganjaran dan hukuman yang tepat
d. Kerjasama yang saling menguntungkan
e. Terwujudnya rasa aman warga sekolah/madrasah


f. Tumbuhnya rasa kepuasan kerja;

g. Tumbuhnya rasa memiliki warga madrasah terhadap sekolah/madrasah

4. Memiliki Tim yang kompak, cerdas, dan dinamis

a. Loyalitas kepada institusi bukan personal

b. Keberhasilan dinyatakan sebagai keberhasilan bersama

c. Mengutamakan keberhasilan lembaga daripada kepuasan pribadi

5. Memiliki kemandirian

a. Mampu mengambil keputusan sendiri

b. Memiliki sumber daya yang memadai

c. Memiliki kemampuan dan kesanggupan kerja secara mandiri

d. Berani mengambil resiko terhadap segala akibat dari keputusan dan pelaksanaan kegiatan

6. Partisipasi Warga Sekolah/Madrasah dan Masyarakat yang tinggi

a. Adanya wadah partisipasi yang dapat menampung dan menyalurkan ide, gagasan, aspirasi, dana, tenaga, sarana dari warga sekolah/madrasah dan masyarakat

b. Terselenggaranya kegiatan partisipasi melalui pertemuan, diskusi, dialog, dsb.

c. Terwujudnya keterbukaan/transparansi dalam pengelolaan madrasah

d. Adanya rasa tanggungjawab bersama antara sekolah/madrasah, masyarakat, pemerintah terhadap keberhasilan sekolah/madrasah

7. Melakukan evaluasi dan perbaikan secara berkelanjutan

a. Ada rencana evaluasi secara terjadwal dan terstruktur b. Ada pedoman dan standar evaluasi yang jelas

c. Hasil evaluasi dapat dibaca semua pihak

d. Hasil evaluasi dijadikan bahan perencanaan dan perumusan kebijakan berikutnya

8. Memiliki akuntabilitas

a. Adanya laporan tertulis kepada steak holders

b. Adanya balikan dari steak holders berupa tanggapan kepuasan atau yang lain

9. Memiliki lulusan yang berprestasi

a. Prestasi akademik sesuai standar sekolah/madrasah

b. Prestasi non akademik sesuai standar sekolah/madrasah

c. Ada daftar alumni dan pelacakannya

10. Penekanan Angka Drop Out

a. Ada program pengayaan

b. Ada program remediasi

c. Ada struktur pembinaan yang berkelanjutan

Indikasi-indikasi tersebut di atas, menjadi cita ideal sekolah/madrasah. Tugas manajemen ialah mewujudkan karakteristik ideal tersebut melalui tahapan-tahapan manajemen yang bertanggungjawab. Saat ini karakteristik ideal proses pendidikan tersebut dapat dilacak dari standar nasional pendidikan yang telah dikeluarkan oleh BNSP (Badan Nasional Standar Pendidikan)

\section{Ad.3. Output pendidikan}

Output pendidikan adalah kinerja sekolah/madrasah.Kinerja dalam hal ini ialah prestasi yang dihasilkan dari proses/pendidikan

di
sekolah/madrasah.Prestasi bisa berupa prestasi akademik dan prestasi non akademik. Kinerja Sekolah/madrasah dapat diukur dari aktivitas, efektifitas, efesiensi, inovasi, kualitas kelulusan, dan 
moral kerja yang menggambarkan mutu yang tinggi.

Melihat kinerja pendidikan dapat ditemukan beberapa aliran/model, yaitu: (1) model tujuan/prestasi; (2) model sistem/proses; dan (3) model kombinasi tujuan dan proses.

1. Model tujuan melihat kinerja pendidikan dari pencapaian tujuan/prestasi akhir. Kinerja sekolah/madrasah dikatakan bermutu, jika (a) seberapa jauh mencapai tujuan; (b) prestasi dalam mencapai tujuan, (c) rata-rata nilai SKHU tinggi. Kelebihan model tujuan ini yaitu mudah diukur, karena hanya mengukur pada sesuatu yang nyata (nilai akhir). Hanya saja model tujuan ini seringkali menimbulkan pola-pola kerja instans, seperti praktek jual beli-manipulasinilai dan tindakan tidak baik yang lain yang justru mengingkari nilai luhur pendidikan. Pendidikan menjadi sekedar mengejar prestasi semu dan kurang memperhatikan kebutuhan perkembangan anak didik.

2. Model Sistem menlihat prestasi pendidikan pada prosesnya dalam memanusiakan manusia. Prestasi ini diukur dari, hal-hal: (a) bagaimana guru melayani siswa dan bagaimana pelayanan sekolah terhadap siswa; (b) bagaimana kebutuhan asasi perkembangan peserta didik terpenuhi; (c) sehingga nilai prestasi ialah pada proses pendidikan yang baik, bukan sekedar tercapainya tujuan dan prestasi nilai semu. Model ini mengukur keberhasilan prestasi pada proses bukan sekedar prestasi Nilai Ujian akhir.Kelebihan model ini sekolah lebih mementingkan kematangan peserta didik dan manajemensekolah/madrasah cenderung stabil karena tidak terpengaruh kebijakan pemerintah yang selalu berubah-ubah-misalnya standar nilai ujian, dan model soal, dll.. Model ini juga memiliki kelemahan, diantaranya prestasi nilai akhir kurang diperhatikan. Peserta didik akan matang sesuai tahapan perkembangan, tetapi nilai ujiannya kurang kompetitif. Oleh karena itu pada sebagian masyarakat yang pragmatis, sekolah yang baik ini cenderung dianggap tidak bermutu, sekalipun secara idealisme pendidikan tercapai.

3. Model kombinasi antara tujuan dan sistem, yaitu mengombinasikan model tujuan dan model sistem.Model ini mengintegrasikan antara tujuan dan sistem/proses, sehinggaproses pendidikan berjalan sesuai idealisme pendidikan, tetapi nilai akhir tidak terlupakan. (c) mencapai tujuan asasi pendidikan dan tujuan praktis dan pragmatis masyarakat.

Output dapat dikatakan bermutu jika dapat memperoleh prestasi akademik dan non akademik yang tinggi. Prestasi akademik berupa: nilai umum, Ujian Sekolah/Madrasah, Ujian Nasional, karya ilmiah, dan lomba-lomba akademik, sedangkan prestaso non akademik seperti, kejujuran, kesopanan, olahraga, ketrampilan, komputer dan kegiatankegiatan lainnya. Mutu sekolah dipengaruhi oleh banyaknya tahapan kegiatan yang saling berhubungan (proses), seperti: perencanaan, pengorganisasin, kepemimpinan, dan pengawasan.

Ad.3. Outcome pendidikan

Outcome pendidikanialah dampak pendidikan setelah siswa lulus dalam jalur konsentrasi pendidikan yang diikuti. Outcome dapat diukur dari 3 hal, yaitu: 1) penerimaan di jalur pendidikan lanjut yang lebih tinggi yang berkualitas sesuai pendidikan yang diikuti; 2) penerimaan oleh dunia kerja/industri yang sesuai jalur 
pendidikan yang diikuti-jika merupakan pendidikan kejuruan atau pendidikan vokasi, dan 3) penerimaan di masyarakat. Ketiga ukuran tersebut menjadi ciri dari kualitas hasil pendidikan yang hakiki.

Outcome pendidikan dasar berkualitas baik, dinyatakan baik apabila mampu diterima pada jalur pendidikan menengah dengan kualitas baik juga. Outcome pendidikan SMK Program Studi Teknik Kendaraan Ringan dinyatakan baik jika dapat bekerja bekerja di bengkel atau perusahaan Otomotif. Begitu juga lulusan UIN/IAIN/STAIN Fakultas Ilmu Tarbiyah dan Keguruan Program Studi PAI akan dianggap baik jika mereka mampu menjadi guru Agama Islam di sekolah/madrasah yang professional dan mampu berkiprah di masyarakat sebagai agen perubahan.

\section{PROBLEMA APLIKASI MANAJEMEN PADA PENDIDIKAN}

Penerapan manajemen pada organisasi pendidikan secara praktik dapat diterima di kalangan para ahli. Sekalipun manajemen awalnya berasal dari organisasi bisnis, penerapan pada organisasi non bisnis seperti pendidikan sangat dimungkinkan. Memang mengelola organisasi bisnis dan organisasi non bisnis ada perbedaan, namun berbagai perbedaan tersebut merupakan bagian kecil dan terletak pada aplikasi manajemen, bukan pada hakekat dan prinsip-prinsipnya. Bahkan letak perbedaan tersebut, menurut Peter F. Drucker tidak lebih dari 10\%-berkaitan dengan aplikasi manajemen, seperti misi, sejarah, istilah-, sedangkan 90\% sama saja Hadi Satyagraha, 2013: 13).

Henri Fayol juga menyatakan hal yang sama, bahwa manajemen bisa diterapkan dalam perusahaan pertambangan, di rumah sakit, maupun di kantor pos. Para manajer di berbagai organisasi menggeluti masalah yang sama, yaitu manusia dalam organisasi (Fayol dalam Satyagraha,2013: 19). Aplikasi berbeda menunjukkan khas organisasi masing-masing.

Berdasarkan hal tersebut di atas, Satyagraha menyebutkan, bahwa pemimpin sebuah perusahaan yang sukses dalam sebuah industri dapat juga sukses memimpin perusahaan yang berbeda bahkan perusahaan yang berbeda industri. Louis Gerstner, mantan CEO yang sukses memimpin perusahaan biskuit Nabisco, sukses memimpin IBM keluar dari ambang kebangkrutan pada tahun 1990-an. Gerstner adalah lulusan MBA Harvard dan tidak pernah memimpin perusahaan komputer ataupun perusahaan berbasis teknologi tinggi. Di Indonesia, Kuntoro Mangkusubroto, dosen Institut Teknologi Bandung (ITB), sukses memimpin turnaround PT Timah, sebuah BUMN dalam industri pertambangan timah. Kuntoro belum pernah memimpin perusahaan tambang timah sebelumnya. Tony Fernandes, akuntan lulusan London School of Economics, University of London, eksekutif perusahaan rekaman Warner Music tidak pernah memimpin perusahaan penerbangan. Namun Fernandes bukan hanya berhasil menyelamatkan AirAsia dari kebangkrutan tetapi juga menjadikannya World's Best Low-Cost Airline selama empat tahun berturut-turut. Kisah sukses Gerstner, Kuntoro, dan Fernandes adalah beberan contoh, bahwa manajemen dapat diterapkan dalam berbagai organisasi berbeda (Hadi Satyagraha, 2013: 19-20). Semua manajer melakukan fungsi manajemen yang sama: merencanakan mengorganisasi, memimpin, dan mengendalikan organisasinya masingmasing. 
Aplikasi manajemen dalam dunia pendidikan memerlukan beberapa pertimbangan, diantaranya, yaitu: (a) sekolah bukan Industri; (b) siswa bukan produk pendidikan; (c) hasil pendidikan identik dengan produk suatu industri; (d) pengguna jasa pendidikan (pelanggan) dapat berwujud siswa, orangtua, pengusaha, dan masyarakat; (e) siswa membutuhkan pendamping dalam proses pendidikannya; dan (f) siswa tidak mempunyai peluang untuk terus mengulang (Myron Tribus). Oleh karena itu ada beberapa ciri manajemen pendidikan yang harus menjadi perhatian dalam rangka menerapkan manajemen dalam pendidikan, sebagai berikut:

1. Manajemen pendidikan bermuara pada kesuksesan perkembangan siswa

2. Manajemen ini sangat bervariasi sejalan dengan keunikan masingmasing para siswa, kondisi kebutuhan dan kebudayaan daerah tempat tinggal mereka yang juga berbeda

3. Karena itu, manajemenpendidikan membutuhkan banyak kiat dan strategi

4. Karena sasaran bertalian dengan psikologi para siswa, maka manajemen ini lebih bertindak secara dikdaktis-metodis dibandingkan dengan melaksanakan peraturanperaturan secara birokrasi, dan

5. Pendidikan adalah milik bersama dan untuk kepentingan semua pihak di lingkungan sekolah. Oleh karena itu manajemenpendidikan berusaha menggalang kerjasama dengan semua pihak dalam melaksanakan misi pendidikan Arief Furchan, (2004:10).

\section{Manajemen Pendidikan Islamsebagai Alternatif Pendekatan Konsep}

Sebagaimana telah dinyatakan pada paragraf terdahulu, bahwa kontribusi manajemen sangat besar terhadap kemajuan pendidikan. Manajemen telah memberikan sumbangsih berharga pada proses pendidikan. Pendidikan menjadi lebih akuntabel, adaptiveness, efektif, dan efesien.

Namun demikian, bukan berarti penerapan manajemen pada pendidikan tidak membawa masalah. Problem yang mengemuka ialah moral dan nilai etika. Banyak teori manajemen-barat termasuk manajemen pendidikan-tidak memasukkan moral dan nilai etika dalam pengembangannya. Menurut Covey dalam (Rosnaini Hashim, 2012) banyak teori tersebut hanya fokus pada motivasi ekonomi, hubungan manusiawi, dan aspek organisasi yang lainRosnaini Hashim, 2012: 168. Oleh karena itu diperlukan pendekatan yang berbeda dalam mengejawantahkan teori manajemen yang lebih humanis dan religius.

Berbeda dengan teori manajemen pendidikan barat, manajemen pendidikan Islam mempunyai konsentrasi dengan mendasarkan kajiannya pada sumber utama Al Qur'an, As Sunah, dan pemikiran dari tokoh Islam terdahulu. Sekalipun bentuknya masih beragam, namun ada harapan besar untuk melahirkan ilmu manajemen pendidikan yang lebih memiliki nilai moral dan etika, sebagaimana cita-cita melahirkan ilmu keislaman. Beberapa pendekatan bisa digunakan untuk melahirkan ilmu manajemen pendidikan Islam, seperti islamisasi sains, filsafat pendidikan Islami, maupun interaktif-interkonektif.

Berdasarkan hal tersebut di atas, manajemen pendidikanIslam dapat didekati dengan pendekatan terapan ini dan juga bisa menggunakan pendekatan paradigmatis. Melalui pendekatan terapan 
ini manajemen pendidikan Islam diartikan sebagai penerapan manajemen pendidikan pada pengembangan mutu lembaga pendidikan Islam (Muhaimin, 2003:314).Sedangkan secara paradigmatis manajemen pendidikan Islam ialah seperangkat konsep manajemen pendidikan yang bersumber dan berlandaskan dari Al Qur'an, As Sunnah, dan pemikiran para tokoh Islam (ijtihad). Penerapan manajemen pendidikan pada lembaga pendidikan Islam akan melahirkan ciri khusus karena LPI tentu saja memiliki misi khusus, budaya organisasi berbeda dengan lembaga pendidikan non LPI. Sedangkan pengembangan paradigma akan mengukuhkan ilmu manajemen pendidikan Islam sebagai bagian ilmu keislaman.

Memahami manajemen pendidikan Islam melalui dua konsentrasi kegiatan, yakni konsep dan praktik akan memberikan konstribusi bagi pengembagan LPI. Konsep manajemen pendidikan Islam ialah sejumlah teori dan konsep untuk merencanakan, mengorganisasi, memimpin, dan mengendalikan pendidikan agar dapat mencapai tujuan yang telah ditentukan secara efektif dan efesien. Konsep ini berkaitan dengan teorisasi manajemen pendidikan Islam, sedangkan praktik merupakan penerapan konsep tersebut di dalam praktik pengembangan lembaga pendidikan Islam. Konsep dan praktik saling berkaitan dan saling mengisi. Konsep manajemen pendidikan Islam lahir dari praktik, sebaliknya praktik manajemen pendidikan Islam pada LPI didasarkan pada konsep. Ketika sumbu konsep dan sumbu praktik terus menerus saling mengisi dan teruji secara empiris akan ilmu manajemen pendidikan Islam.

Pengembangan epistemologi bagi Manajemen Pendidikan Islam ini tidak saja penting untuk memberi konstribusi ilmiah bagi ilmu manajemen pendidikan Islam.Pengembangan ini juga diperlukan agar ilmu manajemen pendidikan Islam dapat diterima sejajar dengan ilmu-ilmu keislaman yang telah lebih dahulu berkembang. Paradigma ini juga dibutuhkan untuk menepis kesan negatif yang seringkali dimunculkan seakan-akan kata Islam pada berbagai ilmu keislaman yang menjadi konsentrasi dan dikembangkan oleh UIN/IAIN/STAIN sebagai sesuatu yang dipaksakan dan mengada-ada. Kata Islam dipandang sebagai sekedar pelabelan pada ilmu yang telah ada sebelumnya dan telah mapan.

Fokus kajian manajemen pendidikan Islam dapat menggunakan beberapa kajian sebagai berikut (Rekomendasi International Annual Conference on Islamic Educational Management I di UIN Maliki Malang, 1-2 Desember 2012):

1. Konsep Manajemen Pendidikan dalam perspektif Islam, meliputi: a) pengertian, b) tujuan, c) fungsi-fungsi, d) subtansi inti dan subtansi ekstensi, dan e) supervisi pendidikan, f) manajemen strategik, g) dan lain sebagainya dalam prespektif Islam (menurut al Qur'an, As Sunnah, dan pemikiran tokoh Islam)

2. Praktik Manajemen Pendidikan pada Lembaga Pendidikan Islam, meliputi strategi dan kiat dalam penerapan manajemen pendidikan pada setiap jenjang dan jalur lembaga pendidikan Islam.

3. Implikasi Manajemen Bisnis pada LPI, berupa implikasi isu dan penyerapan konsep dan strategi manajemen bisnis terbaru dalam penyelenggaraan pendidikan Islam, seperti TQM, Blue Ocean Strategy, Business Canvas Model, dan lain sebagainya. 
Jurnal MPI Vol 1, 2016 


\section{DAFTAR PUSTAKA}

Arismunandar. 2004. Peranan Manajemen Pendidikan Dalam Meningkatkan Mutu Pendidikan, Makalah Disajikan dalam Seminar Internasional Manajemen Pendidikan Yang Efektif dalam Mencapai Keunggulan Mutu Pendidikan, ISMaPI, Jakarta, 29-31 Agustus 2004.

Chatib, Munif. 2013. Gurunya Manusia Menjadikan Semua Anak Istimewa dan Semua Anak Juara. Bandung: Kaifa Learning. Cet. XI.

Dikdasmen. 2001. Manajemen Peningkatan Mutu Berbasis Sekolah, Jakarta: Dikdasmen.

Furchan, Arief. 2004. Transformasi Pendidikan Islam di Indonesia Anatomi Keberadaan Madrasah dan PTAI. Yogyakarta: Gama Media.

Makmur. 2008. Filsafat Administrasi. Jakarta: Bumi Aksara.

Muhaimin. 2003. Arah Baru Pengembangan Pendidikan Islam Pemberdayaan, Pengembangan Kurikulum hingga Redefinisi Islamisasi Pengetahuan. Bandung: Nuansa.

Hadari, Nawawi. 1997. Administrasi Pendidikan, Jakarta: Gunung Agung, Cet. XIV.

Postman, N. \& Weingartner, C. 1973.The School Book: For People Who Want to Know What All The Hollering is about. New York: Delacorte Press.

Hashim, Rosnani. 2012. Educational Management from Islamic Perspective, dalam Proceeding International Annual Conference on Islamic Educational Management. Malang: UIN Maulana Malik Ibrahim Malang.
Satyagraha, Hadi. 2013. The Case Method: Mendidik Manajer Ala Harvard, Jakarta: Penerbit Erlangga.

Silver, H. 1994.Good Schools, Effective Schools: Judgment and Their Histories. London: Cassell.

Tim Dosen Administrasi Pendidikan UPI. 2011. Manajemen Pendidikan. Bandung: Alfabeta.

Tribus, Myron, Total Quality Management in Education. Exergy, inc. Harvard: CA.

Wayson, W.W..Mitchell, B.M., Pinnel, G.S. \& Landis, D. 1988.Up From Exellence: Impact of The Exellence Movement on Schools., Bloomington. Indiana: Phi Delta Kappa Educational Foundation. 



\title{
PEMIMPIN MADRASAH DALAM PERSPEKTIF AL-QUR'AN HADITS
}

\author{
Nurul Yaqien \\ nyaqien@gmail.com \\ Jurusan MPI FITK UIN Maulana Malik Ibrahim Malang \\ Jawa Timur, Indonesia
}

\begin{abstract}
There are various requirements in becoming the leader of madrasah in Islam, such as the existence of justice, honesty, resposibility, emphaty, and so fort, which are pertinent to the expert theories about leadership. It is preferrable that the leader of madrasah come from generous generation because, indirectly, it affects the leadership quality of the leader. Once a person become a leader in madrasah, he must be able to perform very well because it means that he deal with responsibility in the world and in the hereafter. Rasulullah saw. saw forbade people to ask to be a leader, especially when they do not own most leadership aspects. If people insist for that responsibility, Allah swt might will not bless that job, and futhermore, there might be bad things happen in the future, such as students' failure in national examination, lack of school achievement, lack of society reliance, and so forth. These might be happen since basically, Allah swt will not help people who ask for position.
\end{abstract}

Key words:leader, madrasah, Alquran, Hadits

\section{Abstrak}

Ada berbagai persyaratan untuk menjadi pemimpin madrasah dalam Islam, seperti adanya keadilan, kejujuran, tanggung jawab, empati, dan lain sebagainya, yang berkaitan dengan teori para ahli tentang kepemimpinan.Ini adalah lebih baik jika pemimpin madrasah berasal dari generasi yang mempunyai sifat kepribadian tawadhu' karena, secara tidak langsung, hal itu mempengaruhi kualitas kepemimpinan di sebuah madrasah. Setelah seseorang menjadi pemimpin di madrasah, ia harus mampu melakukan dengan sangat baik karena itu berarti bahwa ia mempunyai tanggung jawab di dunia dan di akhirat. Rasulullah saw. melihat orang melarang meminta untuk menjadi pemimpin, terutama ketika mereka tidak memiliki aspek kualitas kepemimpinan yang terbaik. Jika orang bersikeras untuk tanggung jawab itu, Allah swt tidak akan memberkati pekerjaan itu, dan selanjutnya, mungkin ada hal-hal buruk terjadi di masa depan, seperti kegagalan siswa dalam ujian nasional, kurangnya prestasi sekolah, kurangnya ketergantungan masyarakat, dan sebagainya sebagainya. Ini mungkin terjadi karena pada dasarnya, Allah swt tidak akan membantu orangorang yang meminta kedudukan semata.

Kata kunci: Pemimpin, Madrasah, Alqur'an, Hadits

\section{Pendahuluan}

Setiap manusia dalam pendangan Islam adalah pemimpin bagi dirinya sendiri, apakah dia bisa mengatur atau memimpin dirinya sendiri ataukah dia melalaikan dirinya sendiri. Ketika seseorang mampu memimpin dirinya sendiri maka ia akan selamat hidupnya di dunia dan di akhirat. Sebaliknya apabila ia tidak bisa memimpin dirinya sendiri maka ia akan terjerumus dalam kemaksiatan dan dosa. Memimpin diri sendiri memiliki makna bahwa ada raja dalam tubuh manusia yang berupa segumpal darah, apabila segumpal darah itu baik maka seluruh tubuh akan baik dan sebaliknya 